Revista Brasileira de Odontologia Legal - RBOL

\title{
Legal dentistry
}

\section{ETHICAL AND LEGAL ASPECTS OF THE USE OF FAKE DRUGS FOR OROFACIAL AESTHETICS - A CASE REPORT.}

\section{Aspectos éticos e legais do uso de medicamentos falsos para a estética orofacial - relato de caso.}

\author{
Evelyn IBRAHIM ${ }^{1}$, Ademir FRANCO ${ }^{2}$, Mário Marques FERNANDES ${ }^{3}$, Paulo \\ MIAMOTO ${ }^{4}$.
}

1. Aluna do curso de Especialização em Odontologia Legal, Faculdade São Leopoldo Mandic, Instituto de Pesquisas São Leopoldo Mandic, Campinas - SP, Brasil.

2. Professor da Divisão de Odontologia Legal, Faculdade São Leopoldo Mandic, Instituto de Pesquisas São Leopoldo Mandic, Campinas - SP, Brasil.

3. Professor do Departamento de Odontologia Legal da Associação Brasileira de Odontologia Seção Rio Grande do Sul (ABORS), Porto Alegre, RS, Brasil.

4. Perito Odontolegista, Instituto Geral de Perícias de Santa Catarina, Florianópolis - SC, Brasil.

\begin{tabular}{ll}
\hline Information about the manuscript & Corresponding author: \\
Received in: 15 April 2020 & Prof. Dr. Paulo Eduardo Miamoto Dias \\
Accepted in: 01 May 2020 & Odontologia legal e Antropologia Forense, Instituto Geral \\
& de Perícias de Santa Catarina, R. Pastor William Richard \\
& Schisler Filho 590, Itacorubi, Zip code: 88034-100, \\
& Florianópolis, Santa Catarina, Brazil. \\
& E-mail: dr.miamoto@gmail.com.
\end{tabular}

\begin{abstract}
Introduction: Over the last decade, Botulinum Toxin (BT) gained space in the armamentarium of drugs used for orofacial aesthetics. The contemporary scenario of Dentistry led to new horizons within aesthetic treatments founded on the application of BT. Objective: This study aimed to report a case of fake type-A BT sold to a dentist on training for orofacial aesthetics. Material and methods: During a 16-hour training course, a dentist bought form a reference seller a "so-called" quality drug allegedly consisting of type-A BT. After suspecting of fake drug based on uncommon label and flask, the dentist sent images of the product to the laboratory responsible for registering the drug at the National Health Surveillance Agency (ANVISA). Results: The laboratory confirmed the fake drug. ANVISA blocked the commercialization, use and distribution of the product as well as made efforts to remove the available products from the market. Parallel police investigations were carried out and forensic expertise for drug profiling was accomplished confirming the fake drug. Conclusion: This study drives attention to the possibility of existing fake drug commercialization to dentists dedicated to orofacial aesthetics, and the potential impact of this drugs if used in patients. Consequences might extend to penalties in the consumer relation interface, as well as in the criminal field as offense against public health.
\end{abstract}

\section{KEYWORDS}

Botulinum toxin; Drug; Ethics; Forensic dentistry.

\section{INTRODUCTION}

Following technical and scientific development, the functional and aesthetic properties of Botulinum Toxin (BT) entered the spotlight of science. Applications transcended from intramuscular injection for the treatment of spasticity ${ }^{1}$ to corrective use for minimizing signs of aging ${ }^{2}$. Type A BT 
(specifically commercialized in health sciences) became a popular drug in Medicine. Its biochemical effects manifest by directly blocking muscular activity at synaptic level and temporarily hampering contraction ${ }^{3}$. The clinical benefits of this drug gradually raised the attention of dentists.

Brazil is ranked together with countries that host highest numbers of dentists worldwide ${ }^{4}$. Orofacial aesthetics emerged as a promising field in recent dental history in the country ${ }^{5}$. TB use found in this scenario an expanding niche. In Dentistry, TB-based therapeutics include the correction of gummy smile ${ }^{6}$, treatment of bruxism $^{7}$, improvements to orthodontic treatment $^{8}$ and temporomandibular disorders $^{9}$. Aesthetic applications, however, currently represent one the most popular interest among professionals that adhere to this trend.

Counterbalancing this phenomenon, the risk of acquiring and administering fake drugs exists - especially because TB is an unusual product, mainly for less-experienced professionals in the field of orofacial aesthetics. Based on the importance of highlighting the ethical and legal aspects of drug acquisition and administration in Dentistry, the present study aimed to report a case of fake TB bought by a young dentist from an alleged reference seller, during a short course training dedicated to orofacial aesthetics.

\section{CASE REPORT}

In 2017, a short course on facial fillers was provided to dentists. The course had 16 hours and was carried out in two days in Central-Western Brazil.

In the last day of the course, an alleged reference seller approached the students offering type A BT with Botox ${ }^{\text {TM }}$ (Allergan Ltd. ${ }^{\mathrm{TM}}$, Dublin Ireland) label. The drug was offered at US 116.00 (American dollars - nearly $R \$ 580,00$ Brazilian reais) under the usual commercial price. The same drug used along the course, even in patients that volunteered for aesthetic treatment.

One of the students bought six flasks of the product. After showing the drug to a colleague outside the course, suspicion emerged as the label and flask were uncommon (Figure 1). Specifically, the label clearly informed "Botulinum Toxin Type A", serial code $\mathrm{C} 3239 \mathrm{C} 3$ and expiration date of February 2020. The invoice provided by the seller only informed "surgical product".

The student contacted the Brazilian representative of the Botox ${ }^{\mathrm{TM}}$ drug and provided images to be analysed by the company. Internal investigation confirmed the fake product, especially because the serial code was never registered in the company. The Brazilian National Surveillance Agency (ANVISA) was notified in January 2018 and released the Resolution \#115/2018 published in Union's Official Diary (Figure 2). The resolution prohibited the distribution, commercialization and use of the fake drug as well as seizure of the products with the serial code \# C3239C3. 


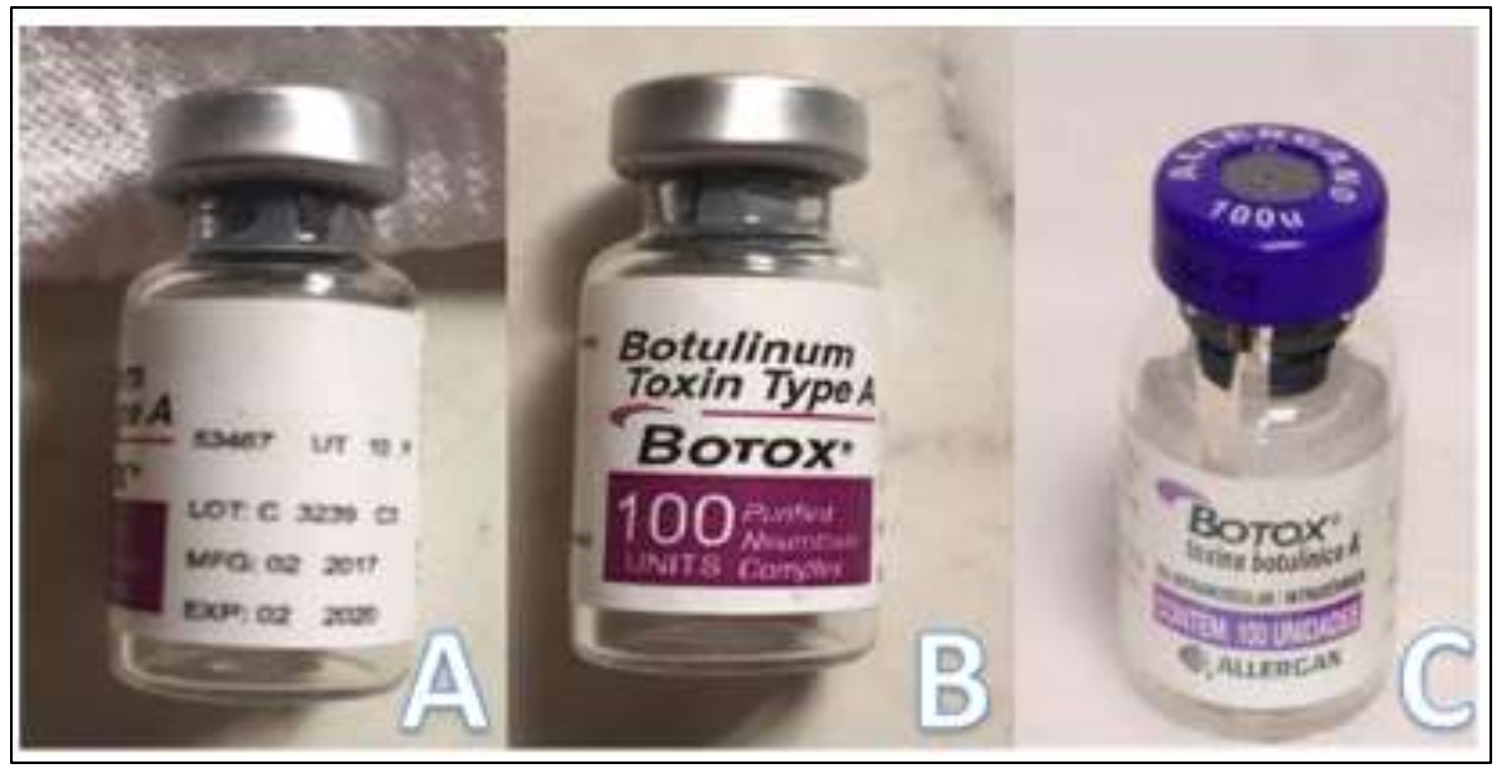

Figure 1 - Posterior $(A)$ and anterior $(B)$ views of the product bought during the short course compared to the official type A BT (C).

\section{RESOLUCCÃO-RE N* 115, DE 12 DE JANEIRO DE 2018}

A Gerente-Geral de Inspeção e Fiscalização Sanitária, Substituta, no uso das atribuiçòes que lhe foram conferidas pela Portaria $n^{\circ} 1.959$, de 24 de novembro de 2017, aliado ao disposto no art. 54 . I. $\S 1^{\circ}$ da Resoluçào da Diretoria Colegiada - RDC n ${ }^{\circ} 61$ de 3 de fevereiro de 2016:

Considerando o art. 62, caput e item II. da Lei $n^{2} 6.360$, de 23 de setembro de 1976 : de 1999:

Considerando $o$ art. $7^{\circ}, \mathrm{XV}$, da Lei $\mathrm{n}^{\circ} 9.782$ de 26 de janeiro

Considerando que a empresa Allergan Produtos Farmacêuticos Ltda., detentora do registro do medicamento BOTOX $100 \mathrm{U}$ (toxina botulinica), pó liofilizado, identificou a falsificação do mesmo por apresentar caracteristicas divergentes daquelas registradas na Anvisa e não sendo os mesmos de procedéncia da empresa, resolve:

Art. $1^{\circ}$ Determinar, como medida de interesse sanitário, a proibiçào da distribuiçào, comércio e uso, bem como a apreensão e inutilizaçào, em todo o território nacional, do medicamento BOTOX $100 \mathrm{U}$ (toxina botulinica), pó liofilizado, lote $\mathrm{C} 3239 \mathrm{C} 3$, tendo em vista que o mesmo nào é procedente do laboratório Allergan Produtos Farmacêticos Ltda., tratando-se, portanto, de falsificaçåo comprovada. blicaçào,

Art. $2^{\circ}$ Esta Resolução entra em vigor na data de sua pu-

\section{MARIANGELA TORCHIA DO NASCIMENTO}

Figure 2 - ANVISA resolution published in Union's Official Diary.

Police investigation was conducted by the local authorities. The case was founded on potential crime against consumer's interests. The crime was inherent to Article $273 \S 1^{\text {st }}$ B-I of the
Brazilian Criminal Code, which describes crime of fake products for medical therapeutics, and Federal Law 8.137/1990, which describes crime within consumer relations. 
Forensic expertise was requested during police investigation to answer the following questions: 1) what are the characteristics of the flask and label of the product, its serial number, date of manufacture and date of expiration?; 2) Was the product registered in the Brazilian National Surveillance Agency? 3A) By means of qualitative analysis, is it possible to state that the product is altered, fraudulent or dangerous to human health? 3B) Is it presented according to regular standards of manufacture, distribution and presentation? 3C) Is it presented with reduced therapeutic value? 3D) Is it presented without identifying information and necessary data for commercialization? 4) Is the product legitimate?

The Brazilian representative of the company provided a sample of the original product as reference for comparative forensic analysis. All the photographs obtained from the flasks were provided to support the analyses and official forensic report. The differences pointed by the experts in the report consisted of the use of vernacular language used in the reference flasks but not used in the questioned product; different font used between reference and questioned materials; and metallic protection with different shapes. Laboratory analyses were not feasible due to lack of available facilities. However, the forensic report concluded by confirming the fake product via qualitative macroscopic external analysis of the flasks.

\section{DISCUSSION}

Knowing

product-specific characteristics and instructions provided by the manufacturer is essential in any field of Dentistry $^{10,11}$. When it comes to Ethics, recent regulations built-up a scenario for dental practice with BT-based products. Over the last eight years, the Brazilian Federal Council of Dentistry released several resolutions that addressed the limits of technical procedures. Resolution \#112/2011 prohibited the use of BT for procedures that were exclusively related to aesthetics and allowed the use for therapeutic dental procedures ${ }^{12}$. Three years later, resolution \#145/2014 maintained the use of BT in Dentistry when justified for therapeutic needs ${ }^{13}$. A month later, resolution \#146/2014 ${ }^{14}$ deemed the matter more obscure by modifying the previous resolution, adding the following text (adapted from Portuguese): "BT is allowed for dental procedures and prohibited for nondental procedures". In 2016, resolution \#176/2016 replaced the previous by stating that BT is allowed in Dentistry for aesthetic and functional therapeutics if used within the anatomic limits of dental practice ${ }^{15}$. The same resolution describes as anatomic limits for dental practice the region between the hyoid bone and Nasion, and anteriorly to the tragus $^{15}$. For non-surgical procedures dedicated to facial harmonization, the upper third of the face was included ${ }^{15}$.

The aesthetic applications authorized by the Brazilian Federal Council of Dentistry, combined with the Brazilian Federal Law 5.081/66 (that authorizes the use of dental knowledge acquired during undergraduation and graduation courses) ${ }^{16}$, triggered the interest of many dentists. Consequently, several courses were designed and offered to dentists that were 
seeking for training. Among these courses, short ones spread over the country made training accessible but not necessarily efficient. These courses were more common before the regulation of orofacial aesthetics as dental specialty. The case reported in this study illustrates the lack of proper selection of sale representatives of BT drugs and brands that affected some of these courses (not generalizing, as it depends on course coordination and structure). These limitations might reflect on students that will not be able to perform in practice with ideal skills - especially if they were trained with non-ideal drugs.

Studies highlight the fact that counterfeit drugs are dangerous by themselves, but fake BT-based drugs are even more dangerous because the main substance of the drug represents a deadly poison ${ }^{17}$. So, the present study raises the following question: "what happens if you give a deadly poison (manifested as fake drug) to a dentist trained for aesthetic applications over a two-day course?" Clearly, a threat to public health is depicted. In order to control the scenario and promote best practices, courses on orofacial aesthetics were better structured in Brazil, under the umbrella of dental specialty. According to Federal Council of Dentistry's resolution \#198/20195 courses on orofacial harmonization must have at least 500 hours. This aspect of the course program enables students to pursue stronger knowledge in the field, especially in relation to pharmaceutics and drug administration. Despite the advances on formal training, the development of knowledge and skills will depend individually on the dentist and his/her ability to develop the predicted competencies of the specialty.

Clinical effects of fake drug administration might include allergies, necrosis, scars and facial deformation. Dentists must be aware of these effects because patients that seek for aesthetic improvement do not wish the opposite. Finding the best training and investigating the origin of medication offered during the course for application in patients are the very first steps towards safe practices in facial aesthetic procedures. Dentists must be aware of the opportunistic courses and drug sellers that see orofacial harmonization as a source of clients that ingenuously buy medication with uncertain description/origin.

\section{FINAL CONSIDERATIONS}

Counterfeit drugs subtly entered the dental market. Opportunistic courses with non-verified drug representatives and sellers took this chance to offer products below the average price. BT figures a drug of interest of many dentists in Brazil, especially among those ongoing training in orofacial aesthetics. Originally, BT is a deadly poison. The drug itself may be a weapon in wrong hands. Consequently, counterfeit BT may be even worse. Dentists must be aware of their choice for training in the field, as well as for the origin of drugs bought along the course. 


\section{RESUMO}

Introdução: Ao longo da última década, a Toxina Botulínica (TB) ganhou espaço no rol de ferramentas utilizadas para a estética orofacial. O cenário odontológico contemporâneo levou a novos horizontes frente a tratamentos estéticos fundamentos na aplicação de TB. Objetivo: O presente estudo objetivou reportar um caso de TB tipo A falsificada adquirida por Cirurgião-dentista que cursava treinamento em estética orofacial. Materiais e métodos: Durante curso de 16 horas de duração, um cirurgião-dentista adquiriu um medicamento supostamente vendido como TB do tipo A. Ao suspeitar do produto pela aparência incomum do seu rótulo e frasco, o profissional enviou imagens para o laboratório responsável pelo registro do mesmo frente à Agência Nacional de Vigilância Sanitária (ANVISA). Resultados: $O$ laboratório confirmou a falta de autenticidade do produto. Neste sentido, a ANVISA proibiu a comercialização, o uso e a distribuição do produto, e determinou sua apreensão e retirada do mercado. Inquérito policial paralelo foi instaurado e pericia de natureza oficial foi conduzida - confirmando a falsidade da droga. Conclusão: Este estudo ressalta a possibilidade da existência de comercialização de drogas falsas para cirurgiões-dentistas dedicados à práticas estéticas orofaciais, e o potencial impacto dessas drogas caso administradas aos pacientes odontológicos. As consequências inerentes podem se estender a penalidades na interface consumerista, assim como à esfera penal como crime contra a saúde pública.

\section{PALAVRAS-CHAVE}

Toxina botulínica; Droga; Ética; Odontologia legal.

\section{REFERENCES}

1. Ozcakir S, Sivrioglu K. Botulinum toxin in poststroke spasticity. Clin Med Res. 2007 ;5(2):132-8. http://doi.org/10.3121/cmr.2007.716.

2. De Boulle K, Fagien S, Sommer B, Glogau R. Treating glabellar lines with botulinum toxin type A-hemagglutinin complex: A review of the science, the clinical data, and patient satisfaction. Clin Interv Aging. 2010; 5:101-18 http://doi.org/10.2147/cia.s9338.

3. Verderio C, Rossetto O, Grumelli C, Frassoni C, Montecucco C, Matteoli M. Entering neurons: botulinum toxins and synaptic vesicle recycling. EMBO Rep. 2006 ;7(10):995-9.

http://doi.org/10.1038/sj.embor.7400796.

4. Franco A. Forensic Dentistry $2^{\text {nd }}$ ed. - book review. Rev Bras Odontol Legal RBOL. 2016; 3(2):138-41. http://doi.org/10.21117/rbol.v3i2.16.

5. Brasil. Resolution CFO-198/2019 establishes orofacial harmonization as a dental especialty. Brasília: Conselho Federal de Odontologia; 2019.

6. Moreira DC, Possidônio FS, De Souza FS, Kinoshita AMO, Silveira EMV. Application of botulinum toxin type A in gummy smile: case report. Rev Gauch Odontol RGO. 2019; 67:e20190013. http://doi.org/10.1590/198186372019000133555.

7. Long $\mathrm{H}$, Liao $\mathrm{Z}$, Wang $\mathrm{Y}$, Liao L, Lai W. Efficacy of botulinum toxins on bruxism: an evidence-based review. Int Dent J. 2012; 62(1):1-5. 595X.2011.00085.X.

8. Srivastava S, Kharbanda S, Pal US, Shah V. Natl J Maxillofac Surg. Applications of botulinum toxin in dentistry: A comprehensive review. Natl J Maxillofac Surg. 2015; 6(2):152-59. http://doi.org/10.4103/09755950.183860
9. Ataran R, Bahramian A, Jamali Z, Pishahang V, Barzegani HS, Sarbakhsh P, et al. The role of botulinum toxin a in treatment of temporomandibular joint disorders: a review. J Dent (Shiraz). 2017; 18(3):157-164.

10. Silva RF, Prado MM, Oliveira HCM, Portilho CDM, Daruge Júnior $\mathrm{E}$. Legal analysis of the instructions for use information in the K-Files packages. RSBO. 2010;7(2):200-7.

11. Silva RF, Prado MM, Oliveira HCM, Portilho CDM, Freitas GC, Daruge Júnior E. Legal analysis of K-File package. Part I information about manufacturers, importers and product features. Rev Odontol UNESP. 2008;37(4):337-43.

12. Brasil. Resolução CFO-112/2011 - baixa normas para a utilização do uso da toxina botulínica e ácido hialurônico. Brasília: Conselho Federal de Odontologia; 2011.

13. Brasil. Resolução CFO-145/2014 - altera a redação de artigos da resolução CFO 112/2011. Brasília: Conselho Federal de Odontologia; 2014.

14. Brasil. Resolução CFO-146/2014 - altera o artigo $2^{\circ}$ da resolução 112/2011. Brasília: Conselho Federal de Odontologia; 2014.

15. Brasil. Resolução CFO-176/2016 - revoga as Resoluções CFO-112/2011, 145/2014 e 146/2014, referentes à utilização da toxina botulínica e preenchedores faciais, e aprova outra em substituição. Brasília: Conselho Federal de Odontologia; 2016.

16. Brasil. Federal Law 5.081/66 - regulates dental practice in Brazil. Brasília: National Congress of Brazil; 1966.

17. Coleman K, Zilinskas RA. Fake botox, real threat. Scientific American. 2010;302(6):8489.

http://doi.org/10.1038/scientificamerican061084. 